\title{
PERBANDINGAN ANTARA KONSEP FIKTIF NEGATIF DALAM UU 5 TAHUN 1986 TENTANG PERADILAN TATA USAHA NEGARA DENGAN KONSEP FIKTIF POSITIF DALAM UU 30 TAHUN 2014 TENTANG ADMINISTRASI PEMERINTAHAN
}

\author{
Erlin Triartha Yuliani \\ Fakultas Hukum, Universitas Indonesia \\ E-mail : erlintriartha@gmail.com
}

\begin{abstract}
Abstrak
Pemerintahan yang baik memiliki peran dalam meningkatkan pelayanan publik Pemerintahan. Pelayanan Publik yang diselenggarakan pemerintah salah satu bentuknya ialah pemberian izin yang tertuang dalam surat keputusan. Akan tetapi faktanya yang terjadi ialah masyarakat sulit untuk mendapatkan permohonan surat keputusan, karena sikap diam pemerintah yang tidak memberi jawaban apakah permohonan tersebut diterima atau tidak. Untuk mengatasi masalah tersebut, jalur yang ditempuh ialah dengan mengajukan gugatan sebagaimana diatur dalam Pasal 3 Undang-Undang Nomor 5 Tahun 1986, atau permohonan sesuai dengan pasal 59 Undang-Undang Nomor 30 Tahun 2014 tentang Administrasi Pemerintahan. Dalam pasal Undang-Undang Administrasi Pemerintahan diatur bahwa berlaku keputusan Fiktif Positif yang berarti sikap diam pemerintah merupakan tindak persetujuan terhadap permohonoan yang diajukan. Sedangkan di Undang-Undang Peradilan Tata Usaha Negara berlaku Fiktif Negartif yang berarti sikap diam pemerintah merupakan tindakan menolak permohonan. Berkaitan dengan dengan adanya dua norma tersebut mengakibatkan ketidakpastian hukum bagi masyarakat untuk mengajukan permohonan/gugatan. Kurang pahamnya masyarakat akan menjadi permasalahan ke depan untuk pemerintahan. Maka dari itu diharapkan pemerintah dapat melakukan harmonisasi peraturan demi memberikan kepastian hukum dan pelayanan publik yang baik bagi masyarakat.
\end{abstract}

\section{Kata Kunci : Pemerintahan Yang Baik; Fiktif Positif; Fiktif Negatif.}

\section{Abstract}

Good governance has a role in improving public services of Government. The Government organized public service one of its forms is the granting of permissions contained in the decision letter. But the fact that occurs is difficult to get a community petition letter decision, because the Government's stillness did not give an answer as to whether the application was accepted or not. To resolve the issue, the path taken is to file a lawsuit as set forth in article 3 of Act No. 5 of the year 1986, or the application pursuant to section 59 of the Act Number 30 year 2014 about government administration. Article Act Administration arranged that Positive Fictitious decision applies which means that 
stillness is the follow government approval against permohonoan asked. Whereas in the judicial act of The State applies a fictitious negative forms which means the Government is silent action stance rejecting the petition. With regard to the presence of two such norms result in legal uncertainty for citizens to apply for/lawsuit. Less pahamnya society will be problems ahead for the Government. Thus it is hoped the Government can perform the harmonization of regulations in order to give legal certainty and good public services for the community.

\section{Key Words: Good Governance; A Fictitious Positive; Negative Fictional.}

\section{Pendahuluan}

Pembukaan Undang-Undang Dasar Negara Republik Indonesia Tahun 1945 mengamanatkan bahwa tujuan didirikan Negara Republik Indonesia, antara lain adalah untuk memajukan kesejahteraan umum dan mencerdaskan kehidupan bangsa. Amanat tersebut mengandung makna negara berkewajiban memenuhi kebutuhan setiap warga negara melalui suatu sistem pemerintahan yang mendukung terciptanya penyelenggaraan pelayanan publik yang prima dalam rangka memenuhi kebutuhan dasar dan hak sipil setiap warga negara atas barang publik, jasa publik, dan pelayanan administrative (Penjelasan Undang-Undang 25 Tahun 2009 tentang Pelayanan Publik). Hal ini menyebabkan meningkatnya tuntutan terhadap pelayanan publik. Pengertian Pelayanan Publik sebagaimana diatur dalam Pasal 1 ayat (1) UU 25 Tahun 2009 tentang Pelayanan Publik ialah, "kegiatan atau rangkaian kegiatan dalam rangka pemenuhan kebutuhan pelayanan sesuai dengan peraturan perundangundangan bagi setiap warga negara dan penduduk atas barang, jasa, dan / atau pelayanan administratif yang disediakan oleh penyelenggara pelayanan publik".

Dewasa ini penyelenggaraan pelayanan publik masih dihadapkan pada kondisi yang belum sesuai dengan kebutuhan dan perubahan di berbagai bidang kehidupan bermasyarakat, berbangsa, dan bernegara. Hal tersebut bisa disebabkan oleh ketidaksiapan untuk menanggapi terjadinya transformasi nilai yang berdimensi luas serta dampak berbagai masalah pembangunan yang kompleks. Salah satu bentuk pelayanan yang sering menimbulkan kekecewaan ialah penerbitan surat keputusan Pejaban TUN kepada masyarakat terkait ijin, akta-akta dalam lainnya. Dalam perjalanannya, masyarakat sering mendapat kendala terhadap surat keputusan tersebut. Kendalanya berupa tidak ada kepastian kapan mendapatkan surat keputusan tersebut, juga terkadang masyarakat rancu apakah permohonan tersebut diterima atau ditolak meskipun persayaratan telah sesuai dengan Standar Operasional Prosedur.

Salah satu penyelesaian mengenai kekecewaan terhadap hal tersebut, dapat dilakukan melalu 
jalur hukum. Hal ini sebagaimana diatur dalam Pasal 1 ayat (3) UUD 1945 berisi bahwa, "Negara Indonesia adalah Negara Hukum.". Berdasarkan hal tersebut, memberikan penguatan bahwa Indonesia yang merupakan negara hukum tidak hanya dilandasi oleh kekuasaan saja. Hukum tidak dapat tegak dengan sendirinya yang mengartikan bahwa hukum tidak mampu mewujudkan norma ke dalam kenyataan (Simanjuntak; 2014). Demi mewujudkan penegakkan hukum tersebut terlebih pada peradilan administrasi dibutuhkan suatu lembaga peradilan administrasi yaitu Peradilan Tata Usaha Negara (selanjutnya disebut PTUN) yang mana pengaturan terhadap PTUN ini diatur melali Undang-Undang Nomor 5 Tahun 1986 tentang Peradilan Tata Usaha Negara (selanjutnya disebut UU PTUN). Dalam pasal 3 UU PTUN dijelaskan bahwa:

(1) Apabila Badan atau Pejabat Tata Usaha Negara tidak mengeluarkan keputusan, sedangkan hal itu menjadi kewajibannya, maka hal tersebut disamakan dengan Keputusan Tata Usaha Negara.

(2) Jika suatu Badan atau Pejabat Tata Usaha Negara tidak mengeluarkan keputusan yang dimohon, sedangkan jangka waktu sebagaimana ditentukan data peraturan perundangundangan dimaksud telah lewat, maka Badan atau Pejabat Tata Usaha Negara tersebut dianggap telah menolak mengeluarkan keputusan yang dimaksud.

(3) Dalam hal peraturan perundang-undangan yang bersangkutan tidak menentukan jangka waktu sebagaimana dimaksud dalam ayat (2), maka setelah lewat jangka waktu empat bulan sejak diterimnya permohonan, Badan atau Pejabat Tata Usaha Negara yang bersangkutan dianggap telah mengeluarkan keputusan penolakan.

Kemudian, dalam penjelasan pasal 3 ayat (2) dijelaskan bahwa Badan atau pejabat tata usaha negara yang menerima permohonan dianggap telah mengeluarkan keputusan yang berisi penolakan permohonan tersebut apabila tenggang waktu yang ditetapkan telah lewat dan badan atau pejabat tata usaha negara itu bersikap diam, tidak melayani permohonan yang telah diterimanya (Harahap; 1997). Hal ini yang disebut keputusan Fiktif Negatif. "Fiktif" menunjukkan bahwa keputusan TUN yang digugat sebenarnya tidak berwujud. Ia hanya merupakan sikap diam dari Badan atau Pejabat TUN, yang kemudian dianggap disamakan dengan sebuah keputusan TUN yang nyata tertulis. "Negatif" menunjukkan bahwa keputusan TUN yang digugat dianggap berisi penolakan terhadap permohonan yang telah diajukan oleh Individu atau badan hukum perdata kepada Badan atau Pejabat TUN.

Di lain hal, dalam UndangUndang Nomor 30 Tahun 2014 tentang Administrasi Pemerintahan (UU AP) juga diatur mengenai permasalahan penyelesaian sengketa keputusan TUN. Warga masyarakat dapat mengajukan gugatan ke Pengadilan Tata Usaha Negara. Selain 
mengajukan gugatan, warga masyarakat dapat mengajukan permohonan fiktif positif. Terkait fiktif positi ini sudah diatur dalam pasal 53 UU AP. Permohonan fiktif positif ialah permohonan yang disebabkan pejabat pemeritahan tidak menetapkan keputusan dan/atau melakukan tindakan dalam waktu sepuluh hari kerja setelah permohonan diterima secara lengkap oleh badan dan/atau pejabat pemerintahan. Berdasarkan latar belakang ini, penulis akan membahas permasalahan: 1 . Bagaimana Perbandingan Konsep Fiktif Negatif dalam UU PTUN dan Konsep Fiktif Positif dalam UU 30 Tahun 2014 tentang Administrasi Pemerintahan guna mewujudkan pelayanan publik yang baik? 2 .

Bagaimana upaya penyelesaian terhadap berlakunya dua Norma tersebut? (Konsep Fiktif Negatif dan Fiktif Positif)?

\section{Metode Penelitan}

Metode penelitaian yang dilakukan dalam penulisan ialah menggunakan pendekatan normatif yaitu berdasarkan penelusuran bahan pustaka atau data sekunder (Diantha; 2017). Data sekunder dalam penelitian ini mencakup (Ashshofa; 2004):

1. Bahan hukum primer yaitu bahan yang berasal dari otoritas tertentu yang

bersifat mengikat dan resmi, yakni berbagai peraturan perundangundangan (baik legislasi maupun regulasi) serta putusan badan peradilan (putusan

Mahkamah

Konstitusi);

2. Bahan hukum sekunder yaitu bahan yang memberikan penjelasan mengenai bahan hukum primer seperti hasil penelitian.

3. Bahan hukum tertier yaitu bahan yang memberikan petunjuk maupun penjelasan terhadap bahan hukum primer dan sekunder seperti kamus, ensiklopedia dan seterusnya. Langkah dalam melakukan penelitian ini yaitu dimulai dengan mengumpulkan bahan primer, bahan sekunder, dan bahan tersier. Bahan tetsebut akan dikaji secara sistematis kemudian disinkronisasikan dengan pokok permasalahan dan teori, untuk menjawab pokok bahasan.

\section{Perbandingan Fiktif Negatif Dalam Pasal 3 UU PTUN dan Fiktif Positif Pasal 53 UU 30 Tahun 2014 Tentang Admnistrasi Pemerintahan}

\section{Melalui Gugatan Fiktif Negatif Berdasarkan Ketentuan Pasal 3 UU PTUN}

Bentuk penyelesaian yang dapat ditempuh untuk menyelesaikan permasalahan sikap diamnya pemerintah ialah melalui jalur hukum. upaya hukum yang dapat ditempuh melalui gugatan fiktif negative dan melalui permohonan untuk mendapatkan keputusan dan/atau tindakan badan atau pejabat pemerintahan yang biasanya diistilahkan keputusan fiktif positif (Rodiing; 2017). Instrumen yang dapat dipakai untuk fikti negative ialah 
pasal 3 UU Noor 5 Tahun 1986 tentang Peradilan Tata Usaha Negara yang berbunyi:

(1) Apabila badan atau pejabat tata usaha negara tidak mengeluarkan keputusan, sedangkan hal itu menjadi kewajibannya, maka hal tersebut disamakan dengan keputusan tata usaha negara.

(2) Jika suatu badan atau pejabat tata usaha negara tidak mengeluarkan keputusan yang dimohon, sedangkan jangka waktu sebagaimana ditentukandalam peraturan perundangundangan dimaksud telah lewat, maka badan atau pejabat tata usaha negara tersebut dianggap telah menolak mengeluarkan keputusan yang dimaksud.

(3) Dalam hal peraturan perundangundangan yang bersangkutan tidak menentukan jangka waktu sebagaimana dimaksud dalam ayat (2), maka setelah lewat jangka waktu empat bulan sejak diterimanya permohonan, badan atau pejabat tata usaha negara yang bersangkutan dianggap telah mengeluarkan keputusan penolakan.

Berdasarkan apa yang telah disebutkan dan dijabarkan melalui ketentuan Pasal 3 UU PTUN, adanya peristilahan sebagai fiktif negatif karena memuat konteks "fiktif" yang menunjukan bahwa KTUN yang menjadi objek gugatan tidak berwujud (Soemitro; 2008). Dan ketentuan pasal ini dimaknai bahwa sikap diam pejabat merupakan bentuk penolakan terhadap permohonan yang diajukan orang atau badan hukum perdata ke pejabat TUN.

Mengenai jangka waktu mengajukan gugatan sebagaimana diatur dalam ayat 2 dan 3, pemohon dapat mengajukan gugatan fiktif negatif apabila permohonan yang diajukan ke termohon (Kementerian) telah lewat 4 bulan sejak diterimanya permohonan. Penghitungan permohonan berdasarkan tanggal penerimaan permohonan oleh Pejabat TUN yang tertera dalam suatu tanda terima.Contoh Keputusan Fiktif Negatif dalam pelayanan Publik: Permohonan Badan HUkum Perdata untuk memperoleh IMB ke Kantor Pelayanan Tata Kota, pemohon sudah melengkapi persyaratan, tetapi sampai dengan tenggang waktu 4 (empat) bulan, belum ada respon dari Kantor Pelayanan Tata Kota. Maka setelah lewat dari 4 Bulan, badan hukum perdata dapat mengajukan gugatan ke Pengadilan Tata Usaha Negara.

Ketentuan Pasal 3 UU PTUN ini, mengartikan bahwa sikap diam dari badan/pejabat TUN telah melanggar AUPB, karena sebagai badan atau pejabat tata usaha negara yang seharusnya dianggap memberikan pelayan baik ke masyarakat justru bertindak sebaliknya. Secara fiktif haruslah dianggap keputusan penolakan ketika lewatnya hari terakhir dari tenggang waktu yang ditentukan (Abdullah; 2015).

Melalui Permohonan Fiktif Positif dalam Pasal 53 UU 30 Tahun 2014 
Penyelesaian sengketa melalui permohonan fiktif positif merupakan kebalikan dari fiktif negatif. Fiktif positif adalah kewenangan Pengadilan untuk memeriksa dan memutus penerimaan permohonan untuk mendapatkan Keputusan dan/ atau Tindakan Badan atau Pejabat Pemerintahan. Permohonan ini didasarkan pada pasal 53 UU Administrasi Pemerintahan:

(1) Batas waktu kewajiban untuk menetapkan dan/atau melakukan Keputusan dan/ atau Tindakan sesuai dengan ketentuan peraturan perundangundangan.

(2) Jika ketentuan peraturan perundang-undangan tidak menentukan batas waktu kewajiban sebagaimana dimaksud pada ayat (1), maka Badan dan/atau Pejabat Pemerintahan wajib menetapkan dan/atau melakukan Keputusan dan/atau Tindakan dalam waktu paling lama 10 (sepuluh) hari kerja setelah permohonan diterima secara lengkap oleh Badan dan/atau Pejabat Pemerintahan.

(3) Apabila dalam batas waktu sebagaimana dimaksud pada ayat (2), Badan dan/atau Pejabat Pemerintahan tidak menetapkan dan/atau melakukan Keputusan dan/atau Tindakan, maka permohonan tersebut dianggap dikabulkan secara hukum.

(4) Pemohon mengajukan permohonan kepada Pengadilan untuk memperoleh putusan penerimaan permohonan sebagaimana dimaksud pada ayat (3).
(5) Pengadilan wajib memutuskan permohonan sebagaimana dimaksud pada ayat (4) paling lama 21 (duapuluh satu) hari kerja sejak permohonan diajukan.

(6) Badan dan/atau Pejabat Pemerintahan wajib menetapkan Keputusan untuk melaksanakan putusan Pengadilan sebagaimana dimaksud pada ayat (5) paling lama 5 (lima) hari kerja sejak putusan Pengadilan ditetapkan

Permohonan ini disebut fiktif positif karena merupakan permohonan yang diandiajukan dianggap adanya keputusan, sedangkan diangap positif karena permohonan yang diajukan oleh pemohon telah diterima dan diajukan permohonan ke pengadilan untuk mendapatkan putusan penerimaan tersebut. Runtutan permohonan dimulai: pemohon mengajukan permohonan ke badan pejabat tun, apabila setelah lewat 10 hari sejak melakukan permohonan tidak mendapatkan jawaban apakah permohonan tersebut diterima/ditolak, sedangkan itu termasuk kewenangan pejaban TUN, maka sikap diam pejabat TUN dianggap bahwa permohonan tersebut dikabulkan. Permohonan yang dikabulkan tersebut kemudian yang menjadi alasan bagi pemohon untuk mengajukan ke Pengadilan agar permohonan yang dikabulkan tersebut segera dikeluarkan putusan atas penerimaan permohonan. Tentunya Pengadilan akan memeriksa apakah permohonan yang dikabulkan tersebut beralasan hukum 
dikabulkan, atau ditolak atau tidak dapat diterima.

Serta apabila dikabulkan, maka Pengadilan memerintahkan kepada bada dan/atau pejabat pemerintahan untuk menerbitkan keputusan atau tindakan terkait permohonan yang dimaksud (Rodiing; 2017). Agar lebih jelas mengenai perbandingan Fiktif Negatif dalam UU PTUN dan Fiktif Positif dalam UU Administrasi Pemerintahan, akan dijelaskan dalam tabel sebagai berikut

Tabel I

Perbandingan Keputusan Fiktif Negatif dan Fiktif Positif (Rodiing; 2017)

\begin{tabular}{|l|l|l|l|}
\hline No. & Perbandingan & $\begin{array}{l}\text { Keputusan Fiktif } \\
\text { Negatif }\end{array}$ & $\begin{array}{l}\text { Keputusan Fiktif } \\
\text { Positif }\end{array}$ \\
\hline 1. & Dasar Hukum & $\begin{array}{l}\text { Pasal 3 Jo Pasal 55 } \\
\text { UU Nomor 5 } \\
\text { Tahun 1986 }\end{array}$ & $\begin{array}{l}\text { Pasal 53 UU } \\
\text { Nomor 30 Tahun } \\
\text { 2014 dan Perma } \\
\text { Nomor 5 Tahun } \\
\text { 2015 }\end{array}$ \\
\hline 2. & $\begin{array}{l}\text { Bentuk } \\
\text { Pengajuan ke } \\
\text { Pengadilan }\end{array}$ & $\begin{array}{l}\text { Dengan Gugatan } \\
\text { Biasa }\end{array}$ & $\begin{array}{l}\text { Dengan } \\
\text { Permohonan }\end{array}$ \\
\hline 3. & Subjek Hukum & $\begin{array}{l}\text { Penggugat: Orang } \\
\text { atau Badan } \\
\text { Hukum Perdata } \\
\text { Tergugat: Badan } \\
\text { atau Pejabat TUN }\end{array}$ & $\begin{array}{l}\text { Pemohon: Pihak } \\
\text { yang } \\
\text { permohonannya } \\
\text { dianggap } \\
\text { dikabulkan secara } \\
\text { hukum }\end{array}$ \\
& & $\begin{array}{l}\text { Termohon: Badan } \\
\text { dan/atau Pejabat }\end{array}$ \\
\hline 4. & Tenggang Waktu & $\begin{array}{l}\text { Diatur dalam ayat } \\
\text { (2) dan (3) yaitu } \\
\text { setelah jangka } \\
\text { waktu } \\
\text { berakhir dan } \\
\text { apabila tidak } \\
\text { diatur } \\
\text { maka jangka } \\
\text { waktunya adalah } \\
4 \text { bulan dan } \\
\text { berpedoman pada } \\
\text { Pasal 55 UU No. 5 }\end{array}$ & $\begin{array}{l}\text { Apabila tenggang } \\
\text { waktu tidak } \\
\text { diatur } \\
\text { dalam peraturan, } \\
\text { maka 10 hari } \\
\text { sejak diajukan } \\
\text { permohonan, } \\
\text { apabila } \\
\text { telah lewat maka } \\
\text { dapat diajukan } \\
\text { permohonan ke } \\
\text { Pengadilan }\end{array}$ \\
\hline
\end{tabular}




\begin{tabular}{|l|l|l|l|}
\hline & & thn 1986 & \\
\hline 5. & Keputusan & $\begin{array}{l}\text { Dianggap } \\
\text { Penolakan }\end{array}$ & $\begin{array}{l}\text { Dianggap } \\
\text { permohonan } \\
\text { diterima/ } \\
\text { dikabulkan }\end{array}$ \\
\hline 6. & Hukum Acara & $\begin{array}{l}\text { Hukum acara } \\
\text { biasa } \\
\text { sebagaimana } \\
\text { diatur dalam UU } \\
\text { Peratun }\end{array}$ & $\begin{array}{l}\text { Sesuai dengan } \\
\text { Perma No. 5 } \\
\text { tahun } \\
\text { 2015 }\end{array}$ \\
\hline 7. & $\begin{array}{l}\text { Pelaksanaan } \\
\text { Putusan }\end{array}$ & $\begin{array}{l}\text { Tidak diatur } \\
\text { waktu } \\
\text { pelaksanaan } \\
\text { putusan apabila } \\
\text { dikabulkan, jadi } \\
\text { tetap merujuk } \\
\text { ke pelaksanan } \\
\text { Putusan pada } \\
\text { acara biasa }\end{array}$ & $\begin{array}{l}\text { Pelaksanaan } \\
\text { Putusan apabila } \\
\text { permohonan } \\
\text { dikabulkan yaitu } \\
\text { paling } \\
\text { lama 5 hari kerja } \\
\text { sejak Putusan } \\
\text { ditetapkan (Pasal } \\
\text { 53 ayat 6 UU No. } \\
\text { 30 } \\
\text { thn 2014 }\end{array}$ \\
\hline
\end{tabular}

Penerapan Konsep Fiktif Positif dalam Persidangan Permohonan di PTUN

Agar lebih memahami mengenai konsep fiktif positif, penulis akan menjelaskan mengenai Permohonan Fiktif Positif yang sudah diajukan ke Pengadilan Tata Usaha Negara sebagai berikut:

\begin{tabular}{|l|l|l|l|}
\hline A. & Pemohon & $:$ & Darwis Rahman, Rektor UKDM \\
\hline B. & Termohon & $:$ & $\begin{array}{l}\text { Ditjen Kelembagaan Kementerian Riset, } \\
\text { Teknologi, Dan Pendidikan Tinggi }\end{array}$ \\
\hline C. & $\begin{array}{l}\text { Objek } \\
\text { Permohonan }\end{array}$ & $:$ & $\begin{array}{l}\text { Keputusan Fikti Positif atas surat dari } \\
\text { Sekretaris Jenderal Legiun Veteran } \\
\text { Republik Indonesia Nomor } \\
\text { D.131/MBLV/X/2017 tanggal 14 } \\
\text { Februari 2017 kepada Termohon yang } \\
\text { pada intinya, sebagaimana disimpulkan } \\
\text { dari Petitum Permohonan, meminta agar }\end{array}$ \\
\hline
\end{tabular}




\begin{tabular}{|c|c|c|c|}
\hline & & & $\begin{array}{l}\text { membatalkan } \\
\text { 5188/C5/KL/2016 tanggal 25 Agustus } \\
2016 \text { perihal Pembentukan Tim } \\
\text { Penyehatan UKDM, dan Surat Nomor } \\
\text { 2182/C.C4/KL/2016 tanggal } 22 \\
\text { November 2016 perihal Permohonan } \\
\text { Pengaktifan PD Dikti UKDM }\end{array}$ \\
\hline D. & Posita & & $\begin{array}{l}\text { 1. Surat Kementerian Riset, Teknologi } \\
\text { dan Pendidikan Tinggi, Direktorat } \\
\text { Jenderal Kelembagaan Ilmu } \\
\text { Pengetahuan Teknologi dan } \\
\text { Pendidikan } \\
\text { Tinggi Nomor:5188/C5/KL/2016 } \\
\text { tanggal 25 Agustus 2016 Perihal: } \\
\text { Pembentukan Tim Penyehatan } \\
\text { UKDM, dan; } \\
\text { 2. Surat Kementerian Riset, Teknologi } \\
\text { dan Pendidikan Tinggi, Direktorat } \\
\text { Jenderal Kelembagaan Ilmu } \\
\text { Pengetahuan Teknologi dan } \\
\text { Pendidikan Tinggi } \\
\text { Nomor:2182/C.C4/KL/2016 tanggal } \\
\text { 22 November 2016 Perihal: } \\
\text { Permohonan Pengaktifan PD Dikti } \\
\text { UKDM; }\end{array}$ \\
\hline E. & Petitum & & $\begin{array}{l}\text { 1. Mengabulkan Permohonan } \\
\text { PEMOHON untuk seluruhnya. } \\
\text { 2. Mewajibkan TERMOHON untuk } \\
\text { membatalkan: } \\
\text { • } \\
\text { Surat Direktur Jenderal } \\
\text { Kemenristek Dikti } \\
\text { Nomor: 5188/C5/KL/2016 tertangg } \\
\text { al } 25 \text { Agustus } 2016 \text { Perihal: } \\
\text { Pembentukan Tim Penyehatan } \\
\text { UKD yang pada } \\
\text { pokoknya Penghentian } \\
\text { Penerimaan Mahasiswa Baru dan } \\
\text { Tri Dharma Perguruan Tinggi. } \\
\text { Surat Direktur Jenderal } \\
\text { Kemenristek Dikti } \\
\text { Nomor: 2182/C.C4/KL/2016 tertan }\end{array}$ \\
\hline
\end{tabular}




\begin{tabular}{|c|c|c|}
\hline & & $\begin{array}{l}\text { ggal 22 November 2016 Perihal: } \\
\text { Permohonan Pengaktifan } \\
\text { Pangkalan Data Dikti UKDM } \\
\text { yang pada pokoknya larangan } \\
\text { Penerimaan Mahasiswa Baru dan } \\
\text { Meluluskan Mahasiswa. yang } \\
\text { telah merugikan PEMOHON } \\
\text { sebesar Rp7.800.000.000,- (tujuh } \\
\text { milyar delapan ratus juta rupiah) } \\
\text { tersebut. } \\
\text { 3. Menghukum TERMOHON untuk } \\
\text { membayar biaya yang timbul dalam } \\
\text { Permohonan a quo. }\end{array}$ \\
\hline F. & Kasus Posisi & $\begin{array}{l}\text { Bahwa pemohon mengajukan surat } \\
\text { permohonan mengenai pengaktifan } \\
\text { kembali status Perguruan Tingi Swasta } \\
\text { yaitu Universitas Karya Darma Makassar. } \\
\text { Bahwa termohon belum dapat } \\
\text { melakukan pengaktifan, karena UKDM } \\
\text { sedang dikenai sanksi administrasi berat. } \\
\text { Bahwa sanksi administratif berat tersebut } \\
\text { dikenai sejak bulan Mei 2016 yang } \\
\text { dimulai dengan mengubah status } \\
\text { Pangkalan Data Pendidikan Tinggi (PD } \\
\text { Dikti) UKDM dari status "aktif" menjadi } \\
\text { status dalam "pembinaan", yang } \\
\text { kemudian diikuti dengan larangan- } \\
\text { larangan, termasuk larangan untuk } \\
\text { menerima mahasiswa baru dan } \\
\text { melakukan ban } \\
\text { mahasiswa. wisuda/meluluskan }\end{array}$ \\
\hline & & $\begin{array}{l}\text { Bahwa pada saat dikenai sanksi } \\
\text { administrasi tersebut pada bulan Mei } \\
\text { 2016, peraturan yang digunakan dalam } \\
\text { menjatuhkan sanksi administratif adalah } \\
\text { Permenristekdikti Nomor } 50 \text { Tahun } 2015 \\
\text { tentang Pendirian, Perubahan, } \\
\text { Pembubaran Perguruan Tinggi Negeri, } \\
\text { dan Pendirian, Perubahan, Pencabutan } \\
\text { Izin Perguruan Tinggi Swasta, yang }\end{array}$ \\
\hline
\end{tabular}




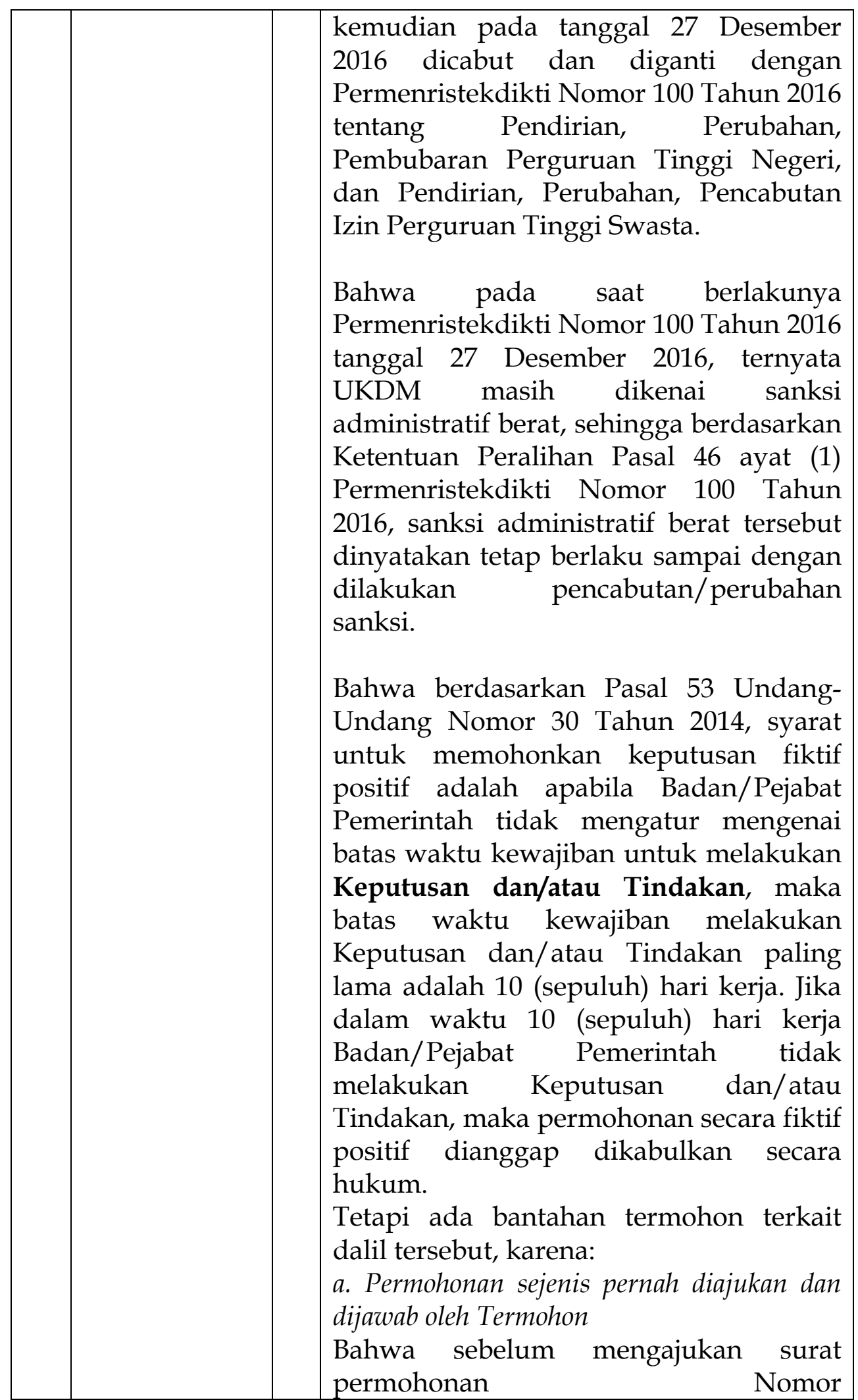




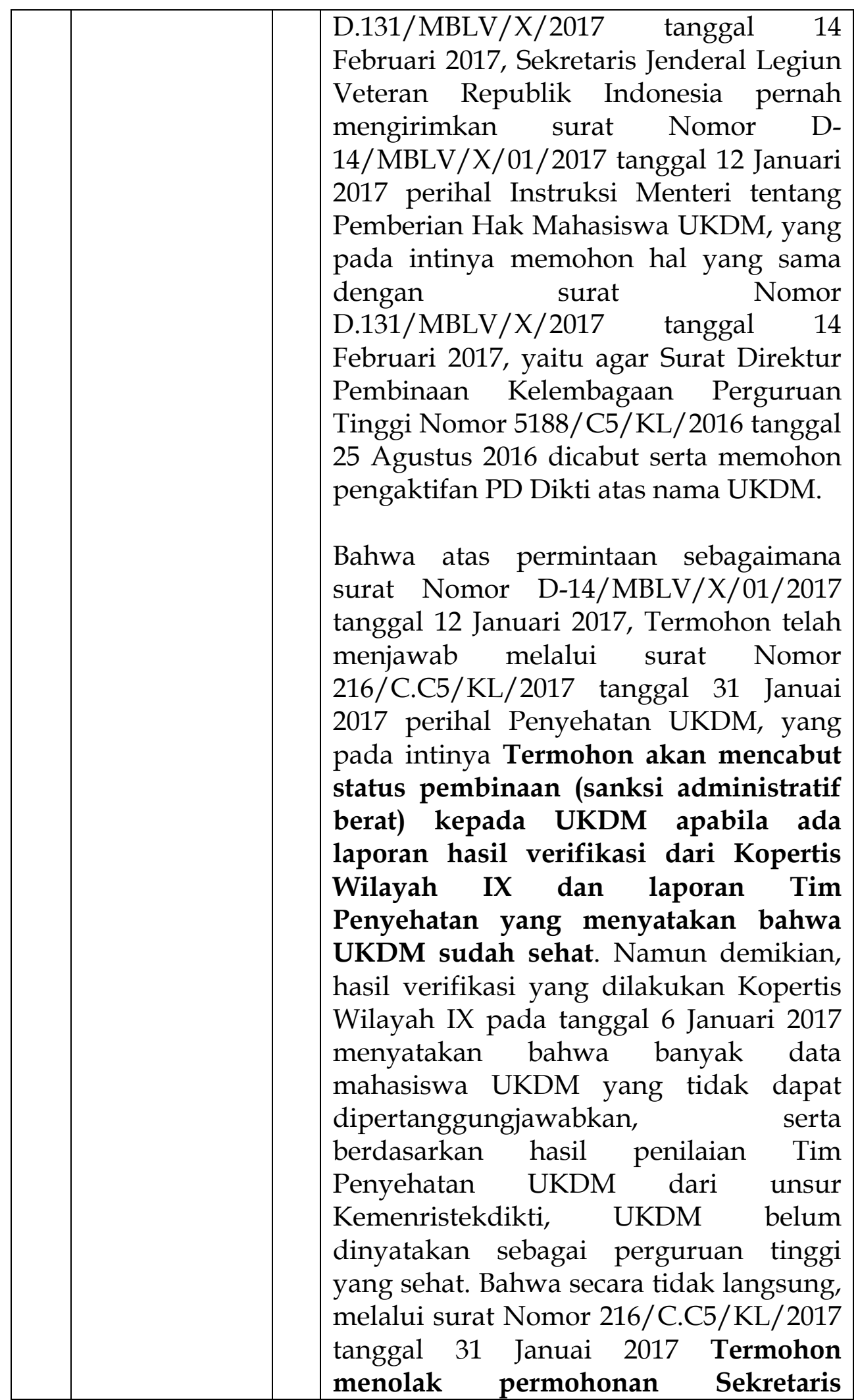




\begin{tabular}{|c|c|c|c|}
\hline & & & $\begin{array}{l}\text { Jenderal LVRI tersebut. } \\
\text { b. Permohonan Pemohon Telah Dijawab Oleh } \\
\text { Termohon Dengan Tindakan } \\
\text { Bahwa terkait dengan UKDM dikenai } \\
\text { sanksi administratif berat, Termohon } \\
\text { dengan itikad baik telah membentuk Tim } \\
\text { Penyehatan UKDM yang di dalamnya } \\
\text { melibatkan Legiun Veteran Republik } \\
\text { Indonesia (LVRI) sebagai badan badan } \\
\text { penyelenggara UKDM, dan Tim } \\
\text { Penyehatan tersebut sudah mulai bekerja } \\
\text { sejak bulan November 2016 sampai } \\
\text { dengan rapat kerja Tim Penyehatan } \\
\text { terkahir diadakan pada tanggal 24 Maret } \\
\text { 2017. Tetapi, sampai dengan saat ini, } \\
\text { Termohon belum melihat adanya } \\
\text { perbaikan secara nyata yang dilakukan } \\
\text { oleh pihak UKDM, sehingga Termohon } \\
\text { memutuskan untuk tidak mencabut } \\
\text { sanksi administrasi berat tersebut. } \\
\text { Dengan dilakukannya rapat kerja Tim } \\
\text { Penyehatan secara intens sampai dengan } \\
\text { terakhir tanggal } 24 \text { Maret 2017, maka } \\
\text { sebenarnya Termohon telah melakukan } \\
\text { Tindakan sebagaimana dimaksud dalam } \\
\text { Pasal } 53 \text { UU Nomor } 30 \text { Tahun 2014 yang } \\
\text { menjawab surat Sekretaris Jenderal } \\
\text { Legiun Veteran Republik Indonesia } \\
\text { Nomor D.131/MBLV/X/2017 tanggal 14 } \\
\text { Februari 2017 dengan tindakan nyata. }\end{array}$ \\
\hline G. & Putusan & & $\begin{array}{l}\text { MENGADILI : } \\
\text { 1. Menyatakan permohonan Pemohon } \\
\text { tidak dapat diterima. (NO) } \\
\text { 2. Menghukum Pemohon untuk } \\
\text { membayar biaya perkara sebesar Rp. } \\
\text { 191.000,- (Seratus sembilan puluh satu } \\
\text { ribu rupiah). }\end{array}$ \\
\hline
\end{tabular}


Mengenai proses penyelesaian perkara permohonan fiktif positif ini, bisa dibilang cepat, karena penyelesaian kasus di atas hanya memakan waktu selama 34 hari, berikut riwayat perkaranya:

\begin{tabular}{|c|c|c|c|}
\hline No. & Tanggal & Tahapan & Proses \\
\hline 1. & $\begin{array}{l}\text { Jumat, } 26 \text { Mei } \\
2017\end{array}$ & $\begin{array}{l}\text { Pendaftaran } \\
\text { Perkara }\end{array}$ & Pendaftaran perkara \\
\hline 2. & $\begin{array}{l}\text { Senin, } 29 \text { Mei } \\
2017\end{array}$ & Penetapan & $\begin{array}{l}\text { Penetapan majelis } \\
\text { hakim }\end{array}$ \\
\hline 3. & $\begin{array}{l}\text { Senin, } 29 \text { Mei } \\
2017\end{array}$ & Penetapan & Penujukan PP \\
\hline 4. & $\begin{array}{l}\text { Senin, } 29 \text { Mei } \\
2017\end{array}$ & Penetapan & Penunjukan Jurusita \\
\hline 5. & $\begin{array}{l}\text { Rabu, } 31 \text { Mei } \\
2017\end{array}$ & Penetapan & $\begin{array}{ll}\text { Penetapan } & \text { Hari } \\
\text { Sidang Pertama } & \end{array}$ \\
\hline 6. & $\begin{array}{l}\text { Senin, } 12 \text { Juni } \\
2017\end{array}$ & Penetapan & Sidang Pertama \\
\hline 7. & $\begin{array}{l}\text { Senin, } 3 \text { Juli } \\
2017\end{array}$ & Persidangan & Persidangan \\
\hline 8. & $\begin{array}{l}\text { Selasa, } 4 \text { Juli } \\
2017\end{array}$ & Putusan & Putusan \\
\hline 9. & $\begin{array}{l}\text { Kamis, } 6 \text { Juli } \\
2017\end{array}$ & Putusan & Minutasi/ \\
\hline
\end{tabular}

\section{Upaya Penyelesaian Berlakunya} Keputusan Fiktif Positif Dan Fiktif Negatif

Perbandingan singkat di atas, memperlihatkan bahwa berlakuya fiktif positif telah bergeser keberlakuannya dari fiktif negatif menjadi fiktif positif. Hal ini dengan alasan bahwa sikap diam pejabat Administrasi dianggap (fiktif) sama dengan menyetujui, sehingga bertolak belakang dengan konsepsi UU Peratun yang menganut asas bahwa sikap diam badan/pejabat TUN adalah dipersamakan dengan suatu penolakan. Dalam konsepsi fiktif positif lebih luas dari itu, karena seandainya pun pejabat pemerintahan sudah menindaklanjuti suatu permohonan namun apabila ketika ditindaklanjuti oleh termohon, ternyata permohonan tersebut dikeluarkan melebihi waktu yang ditentukan, maka dalam hal tersebut permohonan si pemohon harus dianggap sudah dikabulkan oleh termohon.

Atas dasar perbedaanperbedaan tersebut di atas, apabila hukum administrasi Indonesia masih menganut secara konkuren keberlakuan keputusan fiktif negatif 
(UU Peratun) disamping keputusan/tindakan fiktif positif (UUAP) atau dengan kata lain kedua prinsip keputusan/tindakan fiktif ini dipertahankan kedua-duanya secara pararel, maka akan membawa suatu ambivalensi dalam upaya penegakan hukum administrasi. Dampak dari ambilavensi, pada saat sekarang berkembang dua kutub pemikiran yang menyatakan bahwa meskipun dalam UUAP dikenal permohonan fiktif positif namun tidak serta merta gugatan fiktif negatif menjadi tidak dapat diajukan lagi dalam gugatan biasa di Peratun. Hal itu terjadi dikarenakan UUAP dan UU Peratun berbeda rezim, yang pertama berada dalam rezim hukum materil yang kedua berada dalam rezim hukum formal. dikarenakan UUAP dan UU Peratun berbeda rezim, yang pertama berada dalam rezim hukum materil yang kedua berada dalam rezim hukum formal (Enrico Simanjuntak).

Ditambah lagi berlakunya dalam UU AP tidak disertai dengan perubahan UU Peratun, Hal ini yang menimbulkan polarisasi pandangan dikalangan hakim peratun. Dualisme atau polarisasi pandangan semacam ini bahkan terekam dalam salah satu hasil rumusan kegiatan pelatihan teknis para pimpinan PTUN tingkat pertama, yaitu:

“Dengan berlakunya ketentuan Pasal 53 UUAP, bukan berarti secara mutatis mutandis ketentuan Pasal 3 UU Peratun menjadi tidak berlaku, karena Lampiran II huruf C, angka 221 UU No. 12 Tahun 2011, mengatur bahwa pencabutan peraturan perundang-undangan yang sudah tidak berlaku harus dilakukan secara tegas dalam peraturan perundangundangan yang baru. Meskipun secara daya guna norma Pasal 3 UU Peratun sudah tidak efektif, namun demikian pengadilan hendaknya tidak menolak pendaftaran perkara dengan menggunakan dasar Pasal 3 UU Peratun, karena pada prinsipnya pengadilan tidak boleh menolak perkara yang diajukan oleh masyarakat. Terhadap gugatan tersebut dapat disikapi pada tahap dismissal proses oleh Ketua Pengadilan dengan menyatakan gugatan tidak dapat diterima (vide pasal 62 ayat (1) huruf (a) UU Peratun). Demikian juga seandainya suatu gugatan telah diperiksa oleh majelis hakim, maka perkara tersebut dapat disikapi dengan menyatakan gugatan penggugat tidak dapat diterima dengan mendasarkan pada asas lex posteriore derogat legi priori. Pada saat gugatan dengan menggunakan dasar Pasal 3 UU Peratun diajukan ke pengadilan, hendaknya kepaniteraan memberikan saran adanya ketentuan Pasal 53 UU AP tersebut".

Langkah yang dapat ditempuh dalam penyelesaian konflik ini ialah memberlakukan asas Lex posteriori derogat legi priori yaitu undangundang yang baru melumpuhkan undang-undang yang lama, apabila undang-undnag yang baru bertentangan dengan undnag-undang yang lama yang mengatur materi yang sama, maka yang berlaku ada 
undang-undang hukum yang lama (Soedikno Mertokusumo).
Hal ini diperkuat dengan Putusan 27/PEN.DIS/2015/PTUN-Dps

\begin{tabular}{|c|c|c|}
\hline Penggugat & 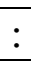 & I Putu Rupadana (Banjar Adat) \\
\hline Tergugat & $:$ & 1. Kepala Kanwil BPN Provinsi Bali \\
\hline & & $\begin{array}{l}\text { 2. Kepala Kantor Pertanahan Kabupaten } \\
\text { Bangli }\end{array}$ \\
\hline $\begin{array}{l}\text { Objek } \\
\text { Gugatan }\end{array}$ & $:$ & $\begin{array}{l}\text { Sertipikat Hak Pakai Nomor 54/Desa } \\
\text { Kawan, Luas } 860 \mathrm{~m} 2 \text { atas nama Dinas } \\
\text { Pekerjaan Umum Provinsi Bali di Denpasar } \\
\text { tanggal 9 Juli } 1987\end{array}$ \\
\hline $\begin{array}{l}\text { Kasus } \\
\text { Posisi }\end{array}$ & : & $\begin{array}{l}\text { Tergugat I dan Tergugat II tidak } \\
\text { memberikan keputusan terkait dengan } \\
\text { permohonan pembatalan objek sengketa } \\
\text { yang diajukan oleh Penggugat, di mana } \\
\text { Tergugat II masih berkoordinasi dengan } \\
\text { Tergugat I sebagaimana Surat Tergugat I } \\
\text { tertanggal } 9 \text { Oktober 2014, lebih lanjut } \\
\text { Penggugat meminta kepastian kepada } \\
\text { Tergugat I atas permohonan pembatalan } \\
\text { objek sengketa. Akan tetapi Tergugat I } \\
\text { belum memberikan keputusan atas } \\
\text { permohonan pembatalan, maka dari itu } \\
\text { Penggugat mendalilkan bahwa Tindakan } \\
\text { Tergugat memenuhi ketentuan pasal } 3 \text { UU } \\
\text { Nomor } 5 \text { Tahun 1986. }\end{array}$ \\
\hline Petitum & & $\begin{array}{l}\text { Pengadilan berpendapat bahwa penggugat } \\
\text { tidak fokus terhadapa gugatannya. } \\
\text { Meskipun objek gugatan berupa } \\
\text { pembatalan sertipikat hak pakai nomor } 54 \text {, } \\
\text { tetapi kontruksi dalil gugatan pengguat } \\
\text { lebih didasark kepada keputusan fiktif } \\
\text { negatif. }\end{array}$ \\
\hline Putusan & & $\begin{array}{l}\text { 1. Menimbang bahwa dengan berlakunya } \\
\text { ketentuan pasal } 53 \text { UU } 30 \text { Tahun } 2014 \\
\text { tersebut, Pengadilan berpendapat } \\
\text { ketetnuan dalam pasal } 3 \text { UU } 5 \text { Tahun } 1986 \\
\text { yang mengatur tentang fiktif negatif } \\
\text { harusla dikesampingkan berdasarkan asas } \\
\text { lex posterior derograt legi priori } \\
\text { 2. Menimbang bahwa meskipun ketentuan }\end{array}$ \\
\hline
\end{tabular}




\begin{tabular}{|l|l|}
\hline & $\begin{array}{l}\text { pasal 3 UU Nomor 5 Tahun } 1986 \text { tidak } \\
\text { dicabut UU 30 Tahun 2014, berdasarkan } \\
\text { asas tersebut, pasal 3 tersebut dianggap } \\
\text { tidak memiliki kekuatan hukum yang } \\
\text { mengikat untuk diterapkan dalam proses } \\
\text { administrasi pemerintahan dalam kerangka } \\
\text { sistem hukum administrasi negara. }\end{array}$ \\
\hline
\end{tabular}

\section{Kesimpulan}

Berdasarkan pembahasan di atas, penulis menarik kesimpulan sebagai berikut:

\section{Penyelesaian}

permasalahan terkait sikap diamnya pemerintah dapa dilakukan melakui 2 cara yaitu:

a. Melalui Gugatan Fiktif Negatif dan

b. Melalui Permohonan untuk mendapatkan keputusan Fiktif Positif

Perbedaan prosedur penyelesaian sengketa tersebut terdiri dari beberapa hal, ditinjau dari konsep, bahwa KTUN Fiktif Negatif "diam ditolak", sedangkan KTUN Fiktif Positif "diam dikabulkan". Dari batas waktunya, KTUN Negatif yaitu yaitu 4 (empat) bulan, sedangkan pada KTUN fiktif positif 10 (sepuluh) hari penyelesaian sengketa melalui Peradilan Tata Usaha Negara batas waktu paling lama 21 (dua puluh satu) hari. Selanjutnya pada KTUN fiktif negatif diajukan melalui gugatan sedangkan KTUN fiktif positif diajukan melalui permohonan. Perbedaan antara gugatan dan permohonan terletak pada prosedur atau hukum acara, sedangkan keduanya sama-sama merupakan sengketa yang menghasilkan putusan
Ditinjau dari batas waktu (daluwarsa) pengajuan gugatan atau permohonan, pada KTUN fiktif negatif 90 (sembilan puluh) hari sejak KTUN fiktif negatif dikeluarkan sedangkan KTUN fiktif positif 90 (sembilan puluh) hari sejak KTUN fiktif positif dikeluarkan. Pada KTUN fiktif negatif, Putusan Peradilan Tata Usaha Negara merupakan putusan akhir sehinggaupaya hukum yang tersedia adalah upaya hukum biasa sedangkan pada KTUN fiktif positif putusan bersifat final dan mengikat, sehingga upaya hukum hanya tersedia upaya hukum luar biasa.

2. Walaupun Fiktif Positif merupakan kebijakan yang ideal dalam mengatasi sikap diamnya pemerintah terhadap permohonan yang diajukan oleh masyarkat, tetapi juga mempunyai kekurangan bahwa karena ada dua norma yang mengatur, terjadi polarisasi kebijakan. Maka dari itu, sebagai solusinya ialah dengan menggunakan asas lex posterior derograt legi priori, yang egatakan bahwa UndangUndang baru mengenyampingkan Undang-Undang lama. Jadi, walaupun keputusan Fiktif Negatis diatur dalam UU PTUN, hal tersebut sudah tidak berlaku lagi karena ada 
UU Administrasi Pemerintahan yang mengantur mengenai keputusan fiktif positif.

\section{Daftar Pustaka}

\section{Undang-Undang}

Republik Indonesia. 1986 UndangUndang Nomor 5 Tahun 1986 tentang Peradilan Tata Usaha Negara. Lembaran Negara Republik Indonesia Tahun 1986 Nomor 77, TLN Nomor 3344.

Republik Indonesia.2004. tentang Perubahan Pertama Atas Undang-Undang Nomor 5 Tahun 1986 tentang Peradilan Tata Usaha Negara. Lembaran Negara Republik Indoneia Tahun 2004 Nomor 35, TLN Nomor 4380

Republik Indonesia. 2009. UndangUndang Nomor 51 Tahun 2009 Perubahan KeduaAtas Undang-Undang Nomor 5 Tahun 1986 tentang Peradilan Tata Usaha Negara Lembaran Negara Republik Indonesia Tahun 2004 Nomor 160, TLN Nomor 5079.

Republik Indonesia. Undang-Undang

Nomor 30 Tahun 2014 tentang Administrasi

Pemerintahan. Lembaran

Negara Republik Indonesia Nomor 292. TLN 4674.

\section{Buku}

Abdullah M, Ali. 2015. Teori dan Praktik Hukum Acara Peradilan Tata Usaha Negara Pasca-
Amandemen, Jakarta: Prenadamedia Group Harahap , Zairin. 1997. Hukum Acara Peradilan Tata Usaha Negara. Jakarta: PT. Raja Grafindo Persada

Soemitro, Rochmat, 2008. Peradilan Tata Usaha Negara, Bandung: Refika Aditama

Yasin, Muhammad dkk.2017 Anotasi Undang-Undang No. 30 Tahun 2014 Tentang Administrasi Pemerintahan. Jakarta: UICSGAR

\section{JURNAL DAN LAIN-LAIN}

Budiaman Rodiing. 2017. Keputusan Fiktif Negatif dan Fiktif Positif dalam Peningkatan Pelayanan Publik, Tanjungpura Law Journal, Vol I, Issue I, January 2017, hal 34

Enrico Simanjuntak, 2014, “Prospek Ombudsman Republik Indonesia Dalam Rangka Memperkuat Pelaksanaan Eksekusi Putusan Peradilan Tata Usaha Negara", Jurnal Hukum dan Peradilan, Vol. 3, No. 2, Juli 2014

Enrico Simanjuntak.2017. "Perkara Fiktif Positif dan Permasalahan Hukumnya", Jurnal Hukum dan Peradilan Vol 6 No 3.

Yodi Martono Wahyunadi. "Kompetensi Absolut Pengadilan Tata Usaha Negara Dalam Konteks Undang-Undang No. 30 Tahun $2014 \quad$ Tentang Administrasi Pemerintahan." Universitas Trisakti, 2016. 
Hasil Rumusan Diklat Kapita Selekta Sengketa Tata Usaha Negara Bagi Pimpinan Pengadilan Tingkat Pertama, mulai tanggal 19 Maret 2017 sampai dengan 25 Maret 2017 di Pusdiklat Mahkamah Agung RI, Megamendung, Bogor 